\title{
PROMOTING DEVELOPMENT PROGRAM EFFECTIVENESS: THE EXPECTED ROLE OF PUBLIC SECTOR AUDIT IN STATE FINANCE MANAGEMENT
}

\begin{abstract}
Andi Wibowo
Universiti Kebangsaan Malaysia

andiwbw@yahoo.com

ABSTRACT

Public sector audit has an important role in development by improving transparency and accountability of state finance management. It is observed, however, that many development programs do not meet their objectives. It indicates that the current public sector audit has not been adequate to promote development program effectiveness. The objective of this study is to confirm whether the current public sector audit approach is not adequate to promote development program effectiveness and what additional roles are expected to be fulfilled by public sector audit. This study is based on the Indonesian context and uses a qualitative methodology where 27 semi-structured interviews were conducted to Member of Parliament and officials of the Supreme Audit Institution (SAI) and government entities in Indonesia. The study shows that the existing public sector audit has not been adequate to promote development program effectiveness because it pays more attention to financial and compliance aspects of the development program. Moreover, it also focuses on a completed development program. Stakeholders expect that public sector audit also needs to provide the solution, provide preventive measures, create a good environment and produce useful information for decision making.
\end{abstract}

\section{KEYWORDS:}

Audit; development; effectiveness; public sector; Supreme Audit Institution 


\section{INTRODUCTION}

Public sector auditing has a prominent role in state finance management by promoting transparency and accountability of government for its stewardship of public money (Nagy, 2015). The audit, which is conducted by the Supreme Audit Institution (SAI), presents to strengthen public accountability by ensuring that public money is spent appropriately (OECD, 2011). SAI also helps citizens and parliaments to monitor government activities through its audit reports (Bringselius, 2015; Reichborn-Kjennerud, Carrington, Gonzales, \& Klarskov, 2015).

The government manages public funds to improve citizens' welfare. The government spends public funds through various development programs in various aspects of peoples' life such as health, education, housing, and income. The spending is a key instrument for economic development. It generates a multiplier effect that eventually will promote the quality of life of people (Wilhelm \& Fiestas, 2005). Wilhelm and Fiestas (2005) also state that good design and implementation of the development programs are important conditions to make sure that the government achieves development objectives. A good design portrays the needs of the program, program's objective, expected outcome and impact and procedures, methods employed and resources needed to achieve the result. A good implementation is needed to actualize the plan so that resources can be properly processed to produce planned output and create intended results. For the spending to create a considerable impact on the citizen, the spending should be carefully planned, executed, monitored and evaluated (World Bank, 2012).

The government sets up an internal control system, to achieve the development program objective, that is designed to ensure that all elements within government institutions work toward achieving development objectives (Asaolu, Adedokun, \& Monday, 2016; Gustavson, 2015; Nurhasanah, 2016). Externally, there is an SAI that is designated as the government's external auditor. Although the role of SAI may vary among countries, it has a common role which is to conduct audit on state finance management in order to promote its transparency and accountability (Domokos, Pulay, Pályi, Németh, \& Mészáros, 2016; INTOSAI, 2013a; Kaya \& Coşkun, 2017; Reichborn-Kjennerud et al., 2015). More specifically, SAI presents to make sure that the government carries out the development programs in accordance with law and regulation in efficient, economical, effective and equitable ways. By evaluating the government's activities and programs through its audits, SAI measures the extent to which the government has managed the state finance properly and reports it to the public. Besides, the audit provides a recommendation that can be used by the government to improve the quality of the development programs. When both internal control and SAI perform their roles properly, quality of development program will improve (Wibowo, Jusoh, Ahmad, \& Malek, 2016).

Despite the contribution of various stakeholders in the development, some development programs did not deliver intended results to citizens. Some facilities are broken during construction such as in the Hambalang case (The Jakarta Post, 2016), some completed projects are idle, underutilized and utilized by ineligible recipients (Wibowo, Jusoh, Ahmad, \& Malek, 2018). Studies by Farwati (2012) and World Bank (2012) exemplify some problems in the implementation of some development programs in Indonesia. Some pro-poor programs, such as cash transfer, health insurance, rice and scholarship for the poor, that are mainly intended to help the poor citizens, suffer from problems such as misallocation and improper distribution of the fund. 
Problems found in some development programs show that the current control mechanism does not work satisfactorily to achieve their intended objectives (Gustavson, 2015). Internally, the government needs to improve the quality of its management so that development can improve the lives of citizens (Riddell, 2004). The government should improve the quality of design and implementation of development programs to make sure that they create the highest value to the citizen. The government also needs to enhance the quality of its internal control and monitoring mechanism to make sure that all components of development programs work as planned. Externally, SAI shall improve the quality of its audit reports because when its audits are conducted properly, the problems should not happen or when they do appear, they can be identified and solved earlier (Wibowo et al., 2016).

Accountability concept demands that government convince the people about the soundness of its development efforts, choices, actions and policies in managing nations' resources and about the impact of its development on their well-being (Dellaportas et al., 2005). Because SAI exists to promote the government's accountability, it should help the government achieve development program objectives so that the program improves the lives of citizens. Thus, SAI presents not only to prove whether the development program succeeds nor not, but to ensure that the program meets its objective (Nagy, 2015).

The government is not the only stakeholder responsible for achieving development program objectives (Wilhelm \& Fiestas, 2005). It means that when the development program fails, the government should not be the only entity that needs to make improvements. In such an occurrence, it is inconceivable that the government shall improve the quality of its internal control. However, it is also true that other stakeholders, including SAI, need to improve their roles as well so that all stakeholders work together to support the government in achieving development program objectives according to their roles and responsibilities (Brétéché \& Swarbrick, 2017).

ISSAI 12 states that SAI needs to play a more important role in state finance management so that its presence adds value to citizens (INTOSAI, 2013a). To perform the role, SAI needs to improve the quality of its audit results so that it can be used by relevant stakeholders for decision-making purposes. In addition, as one of the state institutions, SAI should also be accountable to people for its role in state finance management. Its activities, therefore, should make a difference to the audited program and eventually for the general public. SAI needs to constantly evaluate its works to make sure that they keep abreast with constantly changes the environment and relevant with as well as meet stakeholders' expectation (INTOSAI, 2010; Nagy, 2012).

Wibowo et al. (2016) propose improvement in audit methodology by suggesting that SAI conducts developmental audits. The audit is designed mainly to make sure that development programs meet their objectives. It is proposed because the existing audit has not been adequate to promote development program effectiveness. The objective of this study is to confirm findings by Wibowo et al. (2016) who evaluate the adequacy of existing public sector audit to promote development program effectiveness. Besides, this study also identifies the expected role of public sector audit in addition to existing ones.

Arens, Elder, Beasley, and Hogan (2014) define auditing as "the accumulation and evaluation of evidence about information to determine and report on the degree of correspondence between the information and esta- 
blished criteria. Auditing should be done by a competent, independent person"

That definition portrays necessary conditions for an audit to be conducted, i.e. information, criteria, and a competent and independent person. In an audit, there should be information to be verified and compared against a predetermined standard or criteria which should be agreed upon by both auditor and entity. For the auditor to provide an objective evaluation of the quality of information, an audit should be conducted by independent and competent persons. The definition does not differentiate public and private sector audit and thus is applicable for both audits.

INTOSAI (2013a) defines public-sector auditing as "a systematic process of objectively obtaining and evaluating evidence to determine whether the information or actual conditions conform to established criteria." The audit definition by INTOSAI shows that there is no difference in the nature of audit between public and private sector audits, as it is an effort to measure the conformity of conditions with criteria using available evidence. Although the INTOSAI definition does not include objective and independence, it emphasizes that independence and objectivity are two important factors that affect public sector audit effectiveness (INTOSAI, 2001).

Agency theory states that an audit is designed to reduce the risk of the owner who entrusted assets to the agent to be managed (Madison, 2014). As a mean of accountability, the agent has to report to the owner how well he or she manages the owner's resources. Because of some limitations on the owner's side to examine every side of the agent's operation, the principal hires an independent party to validate the information contained in the agents' report (Waring \& Morgan, 2007). Thus, auditing provides as- surance and adds credibility to the information prepared by management for stakeholders. Without the audit, users of audit reports are doubtful about the quality of information presented by management because management may report misleading information for its interest. This is not an ideal situation because such inaccurate information may lead to poor decisions (Raaum \& Morgan, 2009).

ISSAI mentioned three types of audits, namely financial audit, performance audit and compliance audit (INTOSAI, 2013b). Although the names in each country may vary, the classification embraces the type of audits that are conducted in all SAIs. It is possible for an SAI to conduct a comprehensive audit incorporating two or more types of audits, for example, financial with performance audit or financial with a compliance audit. Those audits are equally important as they have their unique objectives (INTOSAI, 1977).

All of the audits produce conclusions or opinions on government operations or fairness presentation of financial statements. However, the performance audit has distinct characteristics as it provides a recommendation to audited entities to improve their performance (INTOSAI, 2013b). It also produces new information since the existing reporting mechanism does not provide sufficient information about government stewardship such as degree of the economy; efficiency and effectiveness of government operation (Raaum \& Morgan, 2009).

In the performance audit, audit recommendation is required as the audit is intended not only to uncover the weakness and evaluate the performance of government spending; but also to fix any deficiencies and improve entities' performance. Sometimes it is also called value for money audit, operational audit, management audit, program eva- 
luation and even consulting services (Schultz \& Brown, 2003). The difference between performance audit by SAI and works of consulting company is that SAI provides its audit report to parliament and the public, and during the audit, it always considers compliance to regulation as a high priority. Thus, performance audit improves government performance through its recommendation and insight as it tells management how government program should be designed and run. This will guide the government to design and run upcoming programs and activities more efficiently and effectively (Ling \& Dijk, 2009).

Each type of audit has a different contribution to state finance management. Jesus and Eirado (2012) state that the role of audit in the public sector depends on the type of audit conducted. They show that audit opinion produced by financial audit has little to do with entities' performance. A similar result is provided by Akbar and Djazuli (2015) stating that there is no relationship between public welfare and financial audit. They state that performance audit or value for money audit is more appropriate to evaluate performance because according to Agbo and Aruomoaghe (2014), performance audit has a relationship with financial and management performance of government.

There are some studies in public sector audit that highlight the roles of existing public sector audit in promoting the quality of public administration (David, 2017; Domokos et al., 2016; Lungeanu, 2015; Otalor \& Eiya, 2013; Pramono, 2016), reducing inefficient spending (Brétéché \& Swarbrick, 2017; Charles \& Oluoch, 2017; Funnell, Wade, \& Jupe, 2016; Prabowo, Leung, \& Guthrie, 2017; Ramírez \& Pérez, 2016) and combating corruption (Masood \& Afzal, 2016; Raudla, Taro, Agu, \& Douglas, 2015; Reichborn-Kjennerud \& Vabo, 2017). However, some studies reveal that the role of public sector audit is not as expected. Ijeoma and Nwufo (2015), Mamidu, Balogun, and Abilogun (2015) also Masood and Afzal (2016) express their concern about the ineffectiveness of public sector audit in promoting good governance and performance of government. Several factors were identified as contributors to the problem. Some researchers state that the lack of resources, training, knowledge, and capacity building (Masood \& Afzal, 2016; Matendera, 2013) become prominent problems. Other researchers state that lack of professionalism, lack of integrity, low staff motivation, low morale and poor communication also leadership (Gustavson, 2015; Masood \& Lodhi, 2015) are the problems. Other factors are considered as problem that hamper SAI performance such as political interference (Matendera, 2013), non-independence of SAI (Funnell et al., 2016; Ijeoma \& Nwufo, 2015; Mamidu et al., 2015), constitutional limitation to SAI, light punitive sanctions and lack of stakeholders' support (Ijeoma \& Nwufo, 2015).

Some strategies are proposed to improve the role of public sector audit. In addition to improvement in organizational, human resource and external support (Charles \& Oluoch, 2017; Pramono, 2016). Adnyana (2017), and Suartama et al. (2015) suggest that SAI improves the existing audit approach by giving more attention to welfare-related issues. They also recommend that auditors improve the quality of audit plan particularly in the selection of audit objects which should focus on significant programs. Daujotaitè and Mačerinskienè (2008) add that performance audits should use evaluation approaches such as logic models to enhance the quality of audit results.

In addition to the aforementioned audit, Wibowo et al. (2016) introduce a developmental audit concept that will improve the role of SAI in development and maintain its relevance to the people. The audit is intended 
not only to evaluate development programs but also to promote their effectiveness. Sharing some characteristics with existing public sector audit, it has some distinctive features. First, it is conducted in various critical stages of development programs. This approach is necessary to assure that the audited development program runs according to plan in terms of budget, technical specification, and progress, and those audit recommendations from previous audits are followed up properly. Second, developmental audit pays attention to input, process, and result of the audited development program stage. This approach will provide stakeholders with thorough information about the progress and or result of the audited program. Because the result of a certain development stage becomes input for the next stage, this approach is also useful to identify the development problems in their earliest stage.

Third, developmental audit encourages and invites more public participation in the audit. Developmental audit aspires to push public participation further by involving them in the audit, not only as respondents or informants. Fourth, a developmental audit requires SAI to work closely with the government's internal control system so that audit, monitoring and evaluation activities can be carried out efficiently and effectively. This close cooperation is important to avoid work redundancy and to mitigate limited audit resources problems encountered by both SAI and the government's internal audit units. Fifth, a developmental audit necessitates that the follow-up mechanism is improved because regardless of how well any audit is conducted, it will create additional value to the audited program when it provides useful recommendations and that audited entities conduct follow up actions to the recommendations promptly and appropriately.

In the public sector, agency theory states that independent auditors are needed to improve transparency and accountability of state finance management. Improving development program effectiveness is one of the auditors' endeavors to improve government accountability (Badamdorj, 2010). Therefore, SAI through its audit function presents to make sure that the government gets a fair and objective evaluation of the quality of state finance management. The audit also provides parliament and other stakeholders with reliable information for decisions making purpose (Brétéché \& Swarbrick, 2017; Ittonen, 2010; Reichborn-Kjennerud et al., 2015; Reichborn-Kjennerud \& Vabo, 2017; Ríos, Bastida, \& Benito, 2016). Agency theory also requires SAI as a public institution to improve its accountability. It requires SAI to constantly evaluate the quality and relevance of its works with stakeholders' interest to make sure that its works add value to them (INTOSAI, 2013a). The formulation of a better public sector audit approach is an effort to make sure that SAI performs an audit that gives maximum added value for citizens.

Studies about public sector audit show that less attention has been given on evaluating whether the existing audit approach has been adequate to allow SAI to play a greater role in state finance management. As part of the state financial management system, SAI through its audits should contribute to promoting development program effectiveness. The role should be considered as part of SAI's efforts to promote public accountability. The role is also important to highlight the significance and relevance of SAI in promoting public welfare. Existing studies pay more attention to the role of SAI as the evaluator. Most of the research tries to evaluate whether the audit has met a specific goal either in fighting corruption or improving accountability. Those are important roles that SAI can play in state finance management. However, it is also important to know how the SAI role can be improved so that it can make a difference in the life of citizens 
(INTOSAI, 2013a).

\section{RESEARCH METHOD}

This research is based on the Indonesian context and uses a qualitative approach because it analyzes qualitative data (Ritchie, Lewis, Nicholls, \& Ormston, 2013). The research studies participants' knowledge and experience which may differ across participants due to the subjective perspective of participants (Flick, 2009). This study uses purposive sampling or expert sampling (Bhattacherjee, 2012) targeting 27 high-level officials in SAI, Ministry of Public Works and Member of Parliament of Indonesia. The samples were chosen deliberately based on their positions and expertise. The number of sample is considered sufficient as theoretical saturation will be reached at this point where new respondents will not provide additional insights to the research (Bowen, 2005). Interview data to develop the new audit approach were analyzed using thematic analysis which is widely used in qualitative research (Bryman, 2008). The analysis was intended to understand the data by identifying and analyzing themes in the data (Vaismoradi, Turunen, \& Bondas, 2013). The data were analyzed using stages suggested by Braun and Clarke (2006) also Harding (2013) because there were no certain prescribed procedures for the analysis (Bryman, 2008).

In this study, four questions were addressed to interviewees. The questions encompass aspects related to the role of public sector audit in state finance management. The current role of audit in promoting transparency and accountability of state finance management, adequacy and necessity of current audit to promote development program effectiveness and expected role of the audit to promote development program effectiveness were intended to ensure that responses an- swer research objectives. The questions were distributed to interviewees beforehand to allow them to prepare for the interviews.

Soon after the certain interview was completed, its record was transcribed. The transcription also considered notes that were made during interviews to make sure that the transcript did not miss any important message or meaning. After the transcription, all transcribes were read a couple of times to allow the researcher to get acquaintance with the data and get a thorough understanding of the subject matter. The next stage was to generate initial code from the transcription. Using Atlas.ti software, the transcripts were coded using open coding. Although open coding is initially developed for grounded theory, it can be used in other qualitative analysis, including thematic analysis. The code portrays specific feature about the data which allow the researcher to conduct further analysis in a systematic way (Ngulube, 2015).

After the coding process has been completed, the researcher reviewed the identified codes. Some adjustments were made to accommodate similarity and categorization was then made to allow for the theme identification. Theme rises above codes and is built based on groups of codes. It is a product of a thorough understanding of the transcripts (Bryman, 2008; Vaismoradi et al., 2013). Because theme identification intended to capture the essence of the transcripts, initial categorization was not made (Meier, Boivin, \& Meier, 2008). To increase the accuracy of the theme identification process, the researcher repeated the analysis from code categorization to theme identification without looking at the previous analysis. The results were compared, differences were analyzed and final themes were determined. 


\section{RESULT AND DISCUSSION}

All interviewees agreed that the current public sector audit has not been adequate to promote development program effectiveness. They stated that currently, public sector audit tends to pay more emphasis on evaluating the role of audit which focuses on assessing whether or not state finance management has been conducted properly. Less attention has been given on promoting the role of public sector audit to help the government achieves development program objectives. They mentioned that Law Number 15 Year 2004 on State Finance Audit implies that public sector audit should not only evaluate the quality of state finance management but also ensure that it is managed properly. A more comprehensive public sector audit approach, that pays more attention on ensuring effectiveness, is needed to complement the existing role of public sector audit in development so that public sector audits can meet the mandate properly.

The main task of public sector audit is to conduct an audit on management and accountability of state finance. R2, R13, R25, and R27 stated that the audit is intended to provide an evaluation on the government's transparency and accountability by measuring the degree of compliance between condition and relevant standards or criteria. R10, R17, and R19 added that information provided by auditors can tell government and public about the extent to which government officials follow regulation, government spending has been used as intended and the spending has created intended impact. When government spending is utilized properly and as planned, the development program will meet its objective.

The audit is also important to evaluate the quality of the information provided and or used by the government for decision-making purposes because sometimes different institutions provide different data for certain conditions. Analysis of interview data reveals that there are two themes related to fulfilling stakeholders' expectation of a better public sector audit approach. The first theme is about the inadequacy of the existing approach and the second theme is about the expected role of public sector audit that will improve its role in state finance management.

\section{Inadequacies of Existing Roles of Pu- blic Sector Audit in Development}

During the interviews, the question about the existing role of SAI audits in state finance management was addressed. The results of the interviews reveal that, currently, audits conducted by SAI tend to focus on measuring financial and compliance aspects rather than promoting the quality of development. Current audits also tend to focus on completed programs rather than conducting an audit on on-going programs to identify and solve problems during their implementation. The results are summarized in Table 1 . In addition to those aspects, some interviewees highlight other characteristics of SAI audits that reduce their impact on promoting the quality of state finance management. $\mathrm{R} 3$ and R18, for example, stated that lack of coordi-

Table 1. Focus of Existing Public Sector Audit

\begin{tabular}{lc}
\hline \multicolumn{1}{c}{ Description } & Interviewees \\
\hline Focus on measuring and evaluating & $1,2,5,7,8,10,13,15,16,17,22,27$ \\
\hline Focus on compliance aspect & $1,11,12,13,19,20,23,24,25,26,27,6$ \\
\hline Focus on financial aspect & $1,2,4,8,10,12,13,15,17,19,20,26$ \\
\hline Focus on completed programs & All \\
\hline
\end{tabular}


nation and synergy among audit units within SAI makes it difficult for readers of audit reports to get the big picture of development programs.

Interviewees stated that current audits tend to focus on the financial aspect of development programs. It means that monetary value becomes underlying factors affecting audit decisions, such as in measuring audit risk, selecting audit objects, determining the significance of findings and measuring the effect of audit findings. Although the aspect occurs in all audits, it is mostly related to financial audits that deal with assessing the fairness of the figures presented in government entities' financial statements. Although the financial audit is dominant in SAI audit portfolios, interviewees stated that the audit has little relevance with improvement in public welfare because it is intended to provide an audit opinion on the government's financial statements. Any opinion provided by SAI does not change anything because the transactions recorded in the statements have been completed. This finding is consistent with that of Akbar and Djazuli (2015) who state that there is barely any connection between a financial audit and public welfare.
Interviewees also stated that current audits focus on compliance aspects of government programs. Focusing on compliance aspects means that audits come to assess the degree of correspondence between any activities or records with certain standards, laws, and regulations. Although the compliance aspect receives large attention in any public sector audits, it is closely related to compliance audit which is intended to evaluate whether or not certain subject matter has been managed in accordance with relevant regulations. R1 and R15 stated that the compliance aspect is important in development because any noncompliance may detriment the government's effort to manage state resources properly. In the compliance audit, auditors may uncover some non-compliance activities or even corruption. From there, auditors may identify who to be held responsible for the problems and effect of the non-compliances as well as measuring the number of state losses from the failures. However, R6, R14, and R18 argued that the audit gives less benefit for people because what important for people is the quality of development programs and how the programs improve their lives, not information about problems in the programs. In case of failed programs, they further emphasized that number of corrupt officials sent to

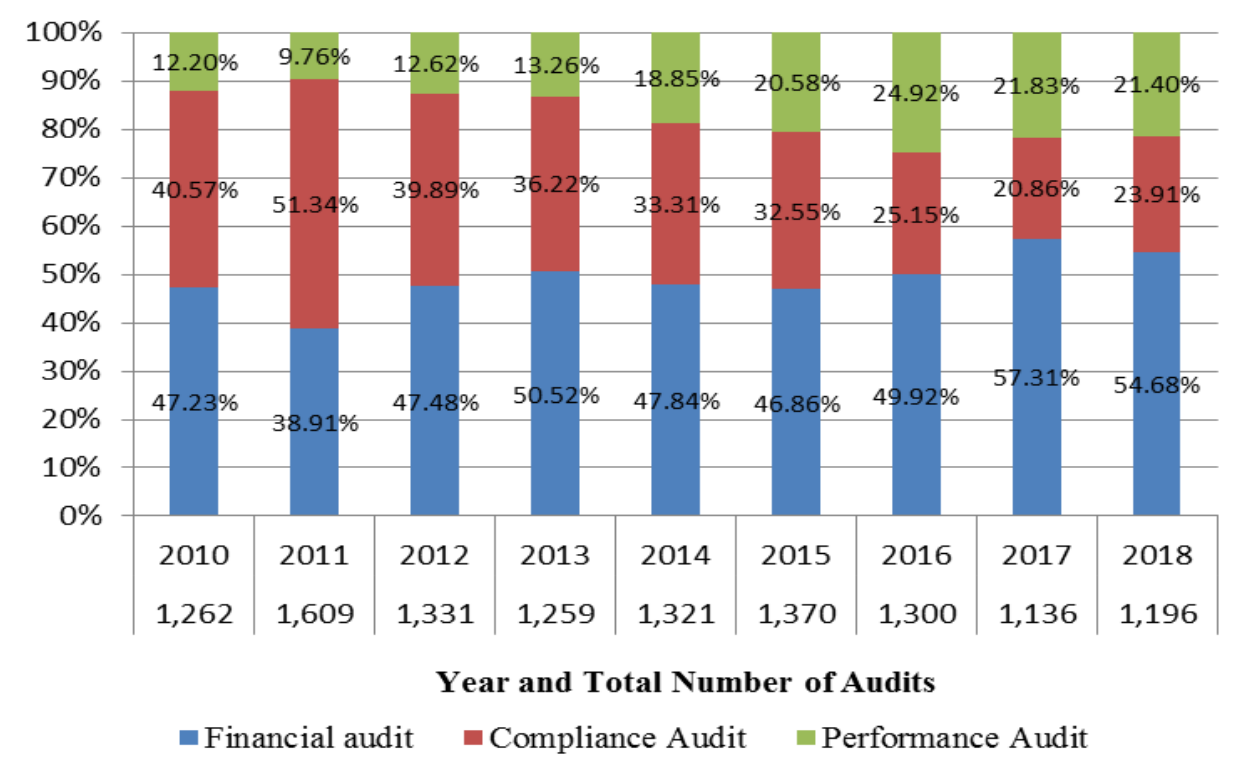

Figure 1. Proportion of SAI Audits 2010-2018

Source: BPK (2010-2019), (processed). 
imprisonment does not change the fact that the program fails to achieve their objectives. Although R15 and R26 stated that compliance audits give deterrence effect for public officials to commit fraud, other interviewees argued that it will be better if efforts are directed to improve governance to prevent fraud happened.

The responses stating that current audits pay more attention to financial and compliance aspects are consistent with audit data in the period of 2010 to 2018 (BPK RI (2010), BPK RI (2011a), BPK RI (2011b), BPK RI (2012a), BPK RI (2012b), BPK RI (2013a), BPK RI (2013b), BPK RI (2014a), BPK RI (2014b), BPK RI (2015a), BPK RI (2015b), BPK RI (2016a), BPK RI (2016b), BPK RI (2017a), BPK RI (2017b), BPK RI (2018a), BPK RI (2018b), BPK RI (2019a)), as shown in Figure 1. Figure 1 portrays that proportion of financial and compliance audits are much higher than that of performance audit. Although the proportion of performance audit is insignificant, Figure 1 shows that the proportion of performance audit is increasing over the years. The proportion of performance audits in 2018 is almost doubled compared with that of in 2010.

Figure 2 supports interviewees' statements saying that current audits pay more attention to compliance aspects. It shows that compliance-related cases are larger than performance-related cases. Three types of audits produce cases in all three general classifications: internal control, compliance, and performance. Thus, Figure 2 exhibits a combination of cases uncovered by all audits from 2010 to 2018. Evaluating internal control and compliance toward regulation is the indispensable function for public sector audit, thus evaluation of both aspects are always conducted by SAI in all types of audits. The compliance findings in Figure 2 are those categorized in-state loss and lack of revenue that the government should receive. A closer look toward internal control cases presented in Figure 2 revealed that, to some extent, they are also related to the compliance aspect. Inaccurate financial data, improper administrative procedures, incompliance to spending procedures and inadequate internal control systems and procedures are ex-

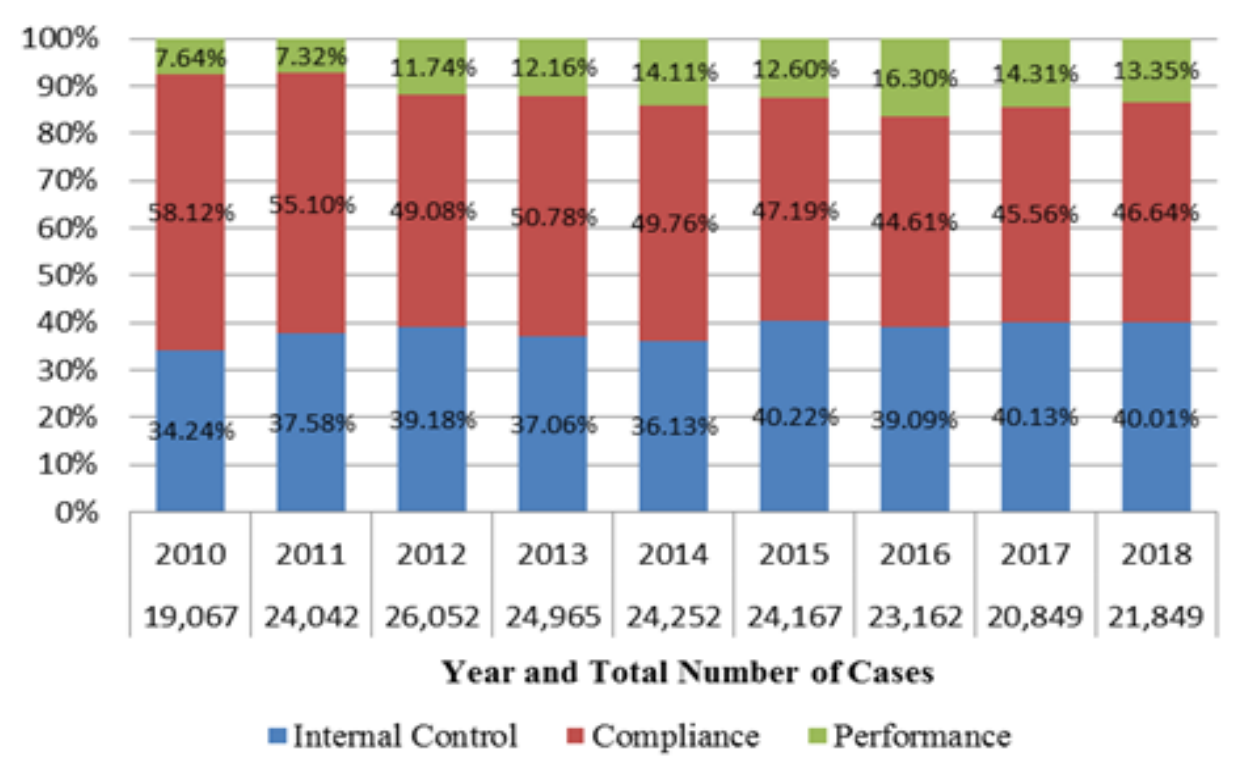

Figure 2. Proportion of Cases Presented in SAI Audit Reports 2010 - 2018 Source: BPK (2010), BPK (2011a), BPK (2011b), BPK (2012a), BPK (2012b), BPK (2013a), BPK (2013b), BPK (2014a), BPK (2014b), BPK (2015a), BPK (2015b), BPK (2016a), BPK (2016b), BPK (2017a), BPK (2017b), BPK (2018a), BPK

(2018b), BPK (2019a), (processed). 
amples of internal control findings. It indicates that most of the internal control cases uncovered in the period are related to compliance issues. With this condition, Figure 2 shows that the proportion of compliancerelated cases is more than $80 \%$ of the total cases reported by SAI in any year.

All interviewees stated that the current audit pays more attention to completed development programs. Focus on completed programs has some advantages. R7 and R10 stated that focusing on completed programs, in any audits, enables auditors to provide a comprehensive evaluation of the programs, from their planning until completion. R1, $\mathrm{R} 15, \mathrm{R} 18, \mathrm{R} 25$, and R27 added that in the completed programs, auditors may identify whether the results of the programs have met intended specifications or standards. When the programs do not meet certain performance indicators, R5 stated that auditors may evaluate the programs from the planning stage to identify weaknesses that contribute to the failures. Focusing on completed programs also minimizes the risk for auditors to be challenged by audited officials because, as R18 described, the effects of any problems found during audits have been taken place. In addition, R2, R8, R10, and R15 revealed a more important reason by stating that conducting an audit on completed programs reduces possible conflict of interest because in such case auditors are not involved in any ways with the audited programs. This enables auditors to provide objective and independent evaluation for the programs.

However, focusing on completed programs gives little benefit to citizens because auditors cannot do anything to change the results of the programs. Regardless of the type of audits conducted, they can only measure what has already happened and produced. Auditors may provide recommendations to improve the programs when the programs are succeeded. When the programs failed, auditors may provide recommendations to recover the damage, minimize the loss and improve the quality of upcoming programs. In the latter case, people, who already missed the benefit of the failed programs, get little benefit from SAI audits. To sum up, all interviewees state that, because of the abovementioned characteristics, existing SAI audits have not been adequate to promote development program effectiveness. To improve SAI's role in improving the government's performance, SAI has tried to improve the proportion of its performance audits. Its decision to improve the proportion of performance audits, from $12.2 \%$ in 2010 to $21.4 \%$ in 2018 is a good start, but interviewees stated that it is not adequate. They stated that although performance audit is more suitable to promote development program effectiveness rather than financial and compliance audits, existing performance audits have not met the expectation because the audits tend to focus on compliance aspect and improving internal government.

Figure 2 also indicates that performance audit reports also contain compliance-related findings because the proportion of performance findings is less than the proportion of performance audits. R2O, R23, R24, and R26 also emphasized that even in the performance audit, where the audit should focus on performance and not on compliance, the audit reports often include non-compliance findings which lead to state loss. Peer Review Report (BPK RI, 2019b) supports the view because it states that the nature of performance audits conducted in BPK is to some extent similar to a compliance audit. The condition underlines the notion that performance audit has not been focused to improve the government's performance. Some performance audits are directed to improve the internal government's performance rather than improving the government's service to people. R11 states “...performance audits that 
we do give more attention to the entity being audited and have not looked at impact of the program to the community". SAI audit reports also reveal that some audit objects for performance audits are not closely related to public welfare. Existing performance audits tend to focus on measuring the quality of the development process and government institutions' accomplishment in meeting their targets or outputs.

Some performance audit objects such as archive management, census activities, research and development activities, appointment and discharge of state-owned enterprises' directors and commissioners, asset management and revenue management are important for government; however R14 stated that SAI should add more audit objects that are important for people and related to public welfare such as audit objects related to health, education, public services, and poverty alleviation.

\section{Expected Roles of Public Sector Audit}

All interviewees agreed that the audit should be intended not only to measure the financial and compliance aspect of development programs but also to promote development pro- grams' effectiveness. They also agreed that the existing audit has not been sufficient to serve the purpose. Public sector audit should also aim to ensure that the development program reaches its objective to improve citizens' quality of life. The audit is intended to ensure that the benefit of development goes to appropriate recipients in correct amount and time without compromising citizens' quality of life.

All interviewees also emphasized that it is part of SAI's responsibility to promote development program effectiveness. They mentioned that although development program effectiveness becomes the government's responsibility, existing laws mandate SAI to ensure that the government meets development objectives. This implies that the audit should be intended not only to measure how well government achieves the objective but also to support the government in achieving the objective. This role applies similarly to a large national development program or in smaller individual programs or projects. Because development programs are intended to improve people's well-being, promoting development programs' effectiveness will improve citizens' quality of life. This highlights a significant position that SAI can play instate finance management through its audit

Table 2. Summary of Responses for Theme Promote Development Effectiveness

\begin{tabular}{lc}
\hline \multicolumn{1}{c}{ Description } & Interviewees \\
\hline $\begin{array}{l}\text { 1. Provide solution and preventive measure } \\
\text { a. } \begin{array}{l}\text { Focuses on attainment of program objective with audit } \\
\text { recommendation }\end{array}\end{array}$ & $1,2,3,4,5,6,7,8,10,11,12,13,14,15,16,22,24,25,26$ \\
\begin{tabular}{l} 
b. Minimizes risk of failures \\
\hline
\end{tabular}
\end{tabular}

2. Create sound environment for development
a. Improves internal control system
$3,5,11,12,14,16,24,26,27$
b. It is not only about fighting corruption and finding mistakes
$6,11,13,14,23,24$
c. More attention should be given on preventing fraud
$3,7,14,26$

3. Produce useful information for decision making
a. Provides foresight
$3,4,6,9,11,12,16,17,18,19,20,23,26$
b. Provide important information
$2,3,4,12,14,15,16,18,19,20,27$ 
function. Table 2 summarizes interviewees' responses on promoting the effective role of public sector audit.

The role of public sector audit in state finance management is to promote transparency and accountability of state finance management. During the audit, auditors always evaluate the extent to which government activities have complied with certain criteria (Arens et al., 2014). With a development perspective, all activities funded by state money, including the audit itself, should benefit the people and contribute to the improvement of people's welfare. It means that the success indicator of public sector audit should be a number of successful programs being audited, not the number of audit findings contained in the audit report. As R13 stated "no matter how many audit findings are reported when many development programs fail to improve citizens' life, an audit has not met its objective." It also means that when there are failed or ineffective projects, or when people's quality of life is below standard and/or not improved, SAI should also be criticized for its lack of support for development. Promoting development program effectiveness can be achieved when a development audit provides solution and preventive measures to the development problem creates a sound environment for development and produces useful information for decision making.

\section{Providing Solution and Preventive Measures}

More than three-quarters of interviewees stated that audit should be directed to provide solutions and provide preventive measures on development problems. More than two-thirds of interviewees stated that the audit should focus on ensuring that the objective of the program is achieved. Moreover, they also emphasized that it is important for SAI to ensure that the government succeeds in achieving the national objectives.
R10 highlighted the importance of this focus by stating that "actually, larger attention should be given on promoting development program effectiveness". R11 added that SAI should also help the government to improve public welfare because the role will complement existing SAI roles in promoting transparency and accountability of government. They stated that although the roles should be considered as part of SAI's roles mandated bylaws, those have not received serious attention.

They stated that auditors should strive to provide useful audit recommendations to help the government achieve development objectives. Recommendations are important to overcome significant development problems and to mitigate the impact of the problems. Auditors may also provide a recommendation to realign the program to its intended objectives when it is about to deviate due to negligence or fraud, or suggest a change to the original plan when the change is necessary to cope with current public demand or condition. R10 stated that an audit should bring a new audit paradigm: "the paradigm should be not only to measure and judge (right or wrong) but also to promote development program effectiveness".

Public sector audit should contribute to the improvement of citizens' lives through its audit findings, conclusions, and recommendations. Audit results portray the government's efforts and achievement in managing development programs along with problems found in the program. The results also contain audit recommendations advising stakeholders on what the government should do to deal with the problems. The information will be used by government, parliament, public, and other stakeholders to make decisions for the program according to their respective roles in development. 
With promoting development program effectiveness paradigm, R22 stated that public sector audit should be able to provide the solution to significant development problems. In addition, R24, and R26 added, it should also be directed to improve the quality of development program so that people will get a bigger benefit from government spending allocated for the program. When audited development programs achieve their intended objectives and citizens receive intended benefits from the programs, R8 and R25 stated that audit activities give additional value for development.

Interviewees stated that an audit needs to prevent a development program from failures. R15 stated that preventing failure is important because when a certain program fails, it "does not bring any benefit for them (citizens or intended beneficiaries) regardless of who is responsible for the failure". Preventing from failure implies that the audit should also be conducted before certain development program is completed because according to R1, R4, and R6, it is where SAI audit recommendations can make a difference. It is different from existing audit which tends to conduct an audit on a completed development program in order to provide a comprehensive evaluation of the program.

Auditors need to engage more active communication with government officials to provide a solution for development problems. When there are problems identified during the audit, auditors need to discuss with government to find the main cause of and solution for the problems, not to find who is the most responsible person causing the problems. This communication is important to raise government officials' awareness about how to deal with the problems and prevent future problems in the same program.

\section{Creating Sound Environment for De- velopment}

Annually, SAI of Indonesia uncovers more than ten thousands audit findings (BPK RI (2010), BPK RI (2011a), BPK RI (2011b), BPK RI (2012a), BPK RI (2012b), BPK RI (2013a), BPK RI (2013b), BPK RI (2014a), BPK RI (2014b), BPK RI (2015a), BPK RI (2015b), BPK RI (2016a), BPK RI (2016b), BPK RI (2017a), BPK RI (2017b), BPK RI (2018a), BPK RI (2018b), BPK (2019a)). This condition shows that currently, the government's internal control system has not been adequate to create good state finance management. Inadequate internal control system gives the opportunity for the negligent decision-making process and even corruption. Almost half of the interviewees stated that an audit should present to create a sound environment for development so that government resources are properly directed to achieve development program objectives.

They stated that to create a sound environment for development, the quality of the government's internal control system should be improved. R14 emphasized that good internal control will strengthen the government's capacity to deliver high-quality programs. R14 added that improving existing internal control system benefits development because the government can be "more focused, more effective and more efficient" toward development objectives. A good quality internal control system demonstrates that, internally, the government has adequate capacity, direction and willingness to attain development objectives. In this case, external oversight will serve as additional support for development by providing the objective and independent evaluation of the program's performance, progress and result.

Improving internal control is conducted through evaluating the adequacy of existing rules, standards, and procedures in the au- 
dited entities and their implementation. SAI may recommend the government to change existing policy and procedures that are considered not giving add value to development. It is also an important role of public sector audit where it does not only use existing regulations as audit criteria but also recommends a change in existing regulation when, based on auditors' evaluation, the regulations do not promote the program's effectiveness.

One important aspect of the government internal control system is the government's internal audit unit. SAI needs to empower internal auditors and encourage them to play a more active role in monitoring development programs because as $\mathrm{R}_{3}$ declared "we need a lot of monitoring in order to work properly". This requires SAI and internal auditors to work together and synergize to watch the development programs more closely. However, because numbers of auditors are limited, relying on auditors to watch development process is not feasible. It is important to create and promote a condition and an environment where government officials are motivated to work properly to achieve development program objectives.

Auditors need to constantly remind the government that the compliance aspect is inherent in public sector audit. However, some interviewees reminded us that an audit should not focus on finding mistakes during the audit because it often frightens auditees in making any decision. In addition, it also discourages government officials to maintain a good relationship and communication with auditors. Therefore, in an audit, more efforts should be directed to find a solution for identified problems. With this perspective, the government is encouraged to discuss any significant problems with auditors because it is the way auditors may contribute in finding appropriate recommendations for the problems. They also stated that it is not important that SAI finds as many audit findings as pos- sible because finding a mistake is not the main objective of an audit. When auditors encounter any audit findings, they need to assess the significance of the problems to objective attainment. In evaluating the findings, they stated that auditors should frame them with effectiveness perspective.

Any violation of procedures, as long as they are not constituted fraud or causing state loss, should be assessed against program delivery or program impact to the people. When any noncompliance to procedures does not affect objective attainment, careful analysis should be conducted whether it is just applicable for specific cases or can be generalized in other cases. If it is proven that there are some steps in the existing procedures that do not add value to the attainment of development objectives, auditors may suggest government to revise existing procedures. It means that an audit also ensures that procedures are designed to help the government achieve development objectives in the most efficient and economical ways. However, when such noncompliance problems create state loss and contain an indication of corruption, SAI may conduct separate compliance audits or investigative audit to further investigate the issues.

Interviewees added that in addition to improving governance, the audit should contribute to the creation of a clean government. Internal systems and procedures should be designed to minimize the opportunity for corruption and to promote anti-corruption behavior. Thus, with respect to combating corruption, more efforts should be directed to prevent corruption from happening, not to uncover it. R3 added that "SAI should cultivate a good culture within government to improve the quality of development program". The culture is important because if government officials work properly only when auditors come to evaluate their works and work otherwise when auditors do not present, auditors will not be able to create a significant 
contribution to development because numbers of auditors are limited. If auditors and government can work together to hone good governance, then with or without an audit, all stakeholders will exert their best effort to support development programs.

The provision of audit reports to the public and involving the public in the audit are other strategies to create a good culture in government. Those mechanisms will increase public awareness and concern for development programs and government activities. They stated that citizens' engagement will promote effectiveness because when there are more parties involved in monitoring activities, government officials will be more prudent in managing the development program.

Good governance and clean government cultures are important for development programs to succeed because they serve as internal checks and balances to avoid any indecent behavior of government officials. They also serve as prevention mechanisms because they may deter fraud and improper operations that will hamper program delivery. Improving good governance culture can be done through conferment of recommendation intended to improve the internal control system. It can also be done through empowering internal audit function because internal audit function can play an important role in promoting good governance culture from within the government.

\section{Producing Useful Information for De- cision Making}

Almost half of the interviewees expected that an audit provides foresight for the government about the consequences of decisions made by the government. When auditors believe that certain policies will have unfavorable impacts on the development program, they need to inform the government about the possible consequences. This role requires auditors to identify the current effect and the possible effect of current policy, strategy, and actions taken by the government to manage the development program. To do this function, auditors need to have a profound understanding of the design and plan of the audited development program. Auditors should also have sufficient knowledge about the program or other similar programs that can be used as a benchmark to improve the quality of audited development programs.

They stated that public sector audit should also use long term perspective and overall benefit in evaluating the program and providing a recommendation to the government. Certain development programs may have unfavorable short term effects for people around the development area, such as river normalization projects that cause some people living in riverbank to lose their houses or Light Rail Transit development that causes a worse traffic jam in certain areas. R12 emphasized that in such a program, SAI should strive to promote the program because they create a larger benefit for citizens in the long term.

More than one-third of interviewees stated that audit results should contain high quality and reliable information for decision-making purposes. They stated that when there is a problem with the development plan; auditors need to explain the consequence of the inadequate plan and provide a recommendation to improve the plan. The government shall use the recommendation to revise the existing plan to avoid further loss, while parliament uses the report to monitor the change and discusses with the government when the change requires an additional budget. This highlights the significant role of public sector audit in supporting development program.

In addition to providing information for government and parliament, audit reports 
should also provide objective and reliable information for citizens about the quality of development programs. People need to know the progress and the result of the development because, according to R4, people have any right to understand how the government manages our money. The information can be used by citizens to give additional support or pressure for the government to provide better quality service for them.

Audit reports should contain significant, accurate and objective information. Because information is important to input for decision -making process, it is expected that with high quality information, government and other stakeholders can make good decisions about the program such as whether to continue, postpone or terminate the program, use existing plan or change the plan, curb or extend the program, add the budget or not, etc. An audit report can be used as a common reference for stakeholders who may have different interests and motives of certain development programs.

The results of this paper strengthen a study by Wibowo et al. (2016) that a better audit approach is needed to improve the role of audit in state finance management. SAI may improve its current audit approach or implement a developmental audit approach formulated by Wibowo et al. (2016). The audit provides a better approach to promote development program effectiveness than existing audits. It will complement existing public sector audit so that the audit will better promote transparency and accountability of the government.

\section{CONCLUSION}

The existing audit approach is considered inadequate to promote development program effectiveness since it pays more attention to financial and compliance aspects of the deve- lopment program. Although compliance to regulation is important to make sure that the development program is planned and executed according to laws and regulations, too much emphasis on the compliance directs auditors to focus on finding mistakes and weaknesses in their audits. Focusing on the financial aspect is important because it helps the auditor to focus on audit activities on programs having large budgets. However, auditors may give less attention to welfare-related programs that have not so large budget.

The current audit also tends to focus on completed development programs. Focusing on the completed program gives readers thorough information about the quality of the program, any deficiencies or problems in the program, the number of state losses incurred and who is responsible for the losses if any. However, the approach gives less opportunity for auditors to contribute to the failed program other than minimizing losses and suggesting an improvement for other programs.

There is a need to improve the existing audit approach to augment the role of SAI in state finance management. The audit should be directed to focus on promoting development program effectiveness. It should provide the solution for identified problems in development programs and even provide preventive measures to avoid or anticipate any significant problems that may jeopardize development program effectiveness. The audit should be able to detect and solve development problems as early as possible so that any mistakes will not be carried along to the very end of the project.

Public sector audit should be able to create a sound environment for development. The audit should be able to strengthen the government's internal control system so that with or without the SAI audit, the government will manage state finance properly to the best interest of citizens. The good internal mecha- 
nism is important to promote development program effectiveness because it is infeasible to expect that auditors will conduct audit on most development programs. The audit should also produce useful information for stakeholders to help them make a good decision.

\section{REFERENCES}

Adnyana, I. G. S. (2017). Understanding audit methods to assist planning on program Evaluation: sharing GAO's experience on national health security program. Jurnal Tata Kelola \& Akuntabilitas Keuangan Negara, 3 (1), 69-89. doi: 10.28986/ jtaken.v3i1.78

Agbo, S., \& Aruomoaghe, J. A. (2014). Performance audit: a tool for fighting corruption in the Nigeria's public sector administration. International Journal of Management and Sustainability, 3(6), 374-383.

Akbar, B., \& Djazuli, A. (2015). Financial audit and people's welfare study in Badung, Tabanan Regions and City of Denpasar Year of 2013. Jurnal Tata Kelola \& Akuntabilitas Keuangan Negara, 1(1), 1-19. doi: 10.28986/ jtaken.v1i1.9

Arens, A. A., Elder, R. J., Beasley, M. S., \& Hogan, C. (2014). Auditing and assurance services: an integrated approach (15th ed.). Boston: Pearson.

Asaolu, T. O., Adedokun, S. A., \& Monday, J. U. (2016). Promoting good governance through internal audit function (IAF): the Nigerian experience. International Business Research, 9(5), 196-204.

Badamdorj, B. (2010). Some thoughts on the role of government auditing. Asian Journal of Government Audit, 2010 (2), 26-29.

Bhattacherjee, A. (2012). Social science research-principles methods and practices. Tampa, Florida: University of South Florida Scholar Commons.

Bowen, G. A. (2005). Preparing a qualitative research-based dissertation: lessons learned. The Qualitative Report, 10 (2).
BPK RI. (2010). Ikhtisar Hasil Pemeriksaan Semester (IHPS) I Tahun 2010 (Summary of Semester Audit Results I Year 2010). Retrieved from https:// www.bpk.go.id/ihps

BPK RI. (2011a). Ikhtisar Hasil Pemeriksaan Semester (IHPS) II Tahun 2010 (Summary of Semester Audit Results II Year 2010). Retrieved from https://www.bpk.go.id/ihps

BPK RI. (2011b). Ikhtisar Hasil Pemeriksaan Semester (IHPS) I Tahun 2011 (Summary of Semester Audit Results I Year 2011). Retrieved from https:// www.bpk.go.id/ihps

BPK RI. (2012a). Ikhtisar Hasil Pemeriksaan Semester (IHPS) II Tahun 2011 (Summary of Semester Audit Results II Year 2011). Retrieved from https:// www.bpk.go.id/ihps

BPK RI. (2012b). Ikhtisar Hasil Pemeriksaan Semester (IHPS) I Tahun 2012 (Summary of Semester Audit Results I Year 2012). Retrieved from https:// www.bpk.go.id/ihps

BPK RI. (2013a). Ikhtisar Hasil Pemeriksaan Semester (IHPS) II Tahun 2012 (Summary of Semester Audit Results II Year 2012). Retrieved from https://www.bpk.go.id/ihps

BPK RI. (2013b). Ikhtisar Hasil Pemeriksaan Semester (IHPS) I Tahun 2013 (Summary of Semester Audit Results I Year 2013). Retrieved from: https:// www.bpk.go.id/ihps

BPK RI. (2014a). Ikhtisar Hasil Pemeriksaan Semester (IHPS) II Tahun 2013 (Summary of Semester Audit Results II Year 2013). Retrieved from https:// www.bpk.go.id/ihps

BPK RI. (2014b). Ikhtisar Hasil Pemeriksaan Semester (IHPS) I Tahun 2014 (Summary of Semester Audit Results I Year 2014). Retrieved from https:// www.bpk.go.id/ihps

BPK RI. (2015a). Ikhtisar Hasil Pemeriksaan Semester (IHPS) II Tahun 2014 (Summary of Semester Audit Results II Year 2014). Retrieved from https://www.bpk.go.id/ihps

BPK RI. (2015b). Ikhtisar Hasil Pemeriksaan Semester (IHPS) I Tahun 2015 (Summary of Semester Audit Results I Year 2015). Retrieved from https:// www.bpk.go.id/ihps 
BPK RI. (2016a). Ikhtisar Hasil Pemeriksaan Semester (IHPS) II Tahun 2015 (Summary of Semester Audit Results II Year 2015). Retrieved from https:// www.bpk.go.id/ihps

BPK RI. (2016b). Ikhtisar Hasil Pemeriksaan Semester (IHPS) I Tahun 2016 (Summary of Semester Audit Results I Year 2016). Retrieved from https:// www.bpk.go.id/ihps

BPK RI. (2017a). Ikhtisar Hasil Pemeriksaan Semester (IHPS) II Tahun 2016 (Summary of Semester Audit Results II Year 2016). Retrieved from https:// www.bpk.go.id/ihps

BPK RI. (2017b). Ikhtisar Hasil Pemeriksaan Semester (IHPS) I Tahun 2017 (Summary of Semester Audit Results I Year 2017). Retrieved from https:// www.bpk.go.id/ihps

BPK RI. (2018a). Ikhtisar Hasil Pemeriksaan Semester (IHPS) II Tahun 2017 (Summary of Semester Audit Results II Year 2017). Retrieved from https:// www.bpk.go.id/ihps

BPK RI. (2018b). Ikhtisar Hasil Pemeriksaan Semester (IHPS) I Tahun 2018 (Summary of Semester Audit Results I Year 2018). Retrieved from https:// www.bpk.go.id/ihps

BPK RI. (2019a). Ikhtisar Hasil Pemeriksaan Semester (IHPS) II Tahun 2018 (Summary of Semester Audit Results II Year 2018). Retrieved from https:// www.bpk.go.id/ihps

BPK RI. (2019b). Peer review report on the Audit Board of the Republic of Indonesia. Jakarta: BPK RI.

Braun, V., \& Clarke, V. (2006). Using thematic analysis in psychology. Qualitative Research in Psychology, 3(2), 77-101.

Brétéché, B., \& Swarbrick, A. (2017). Developing effective working relationships between supreme audit institutions and parliaments. SIGMA Papers No. 54 .

Bringselius, L. (2015). In the absence of a public accounts committee: the Swedish experience. In Z. Hoque (Ed.), Making Governments Accountable. London/New York: Routledge.

Bryman, A. (2008). Social research methods (3rd ed.). London: Oxford University Press.
Charles, B. K., \& Oluoch, O. (2017). Determinants of the effectiveness of the auditor general in kenya in public financial management oversight. The Strategic Journal of Business \& Change Management, 4(2), 98 - 112.

Daujotaitè, D., \& Mačerinskienè, I. (2008). Development of performance audit in public sector. Paper presented at the 5 th International Scientific Conference Business and Management, Vilnius, Lithuania.

David, R. (2017). Contribution of records management to audit opinions and accountability in government. South African Journal of Information $\mathrm{Ma}$ nagement, 19(1), 771-784.

Dellaportas, S., Gibson, K., Alagiah, R., Hutchinson, M., Leung, P., \& Van Homrigh, D. (2005). Ethics, governance \& accountability, a professional perspective. Brisbane: JohnWiley \& Sons Australia Ltd.

Domokos, L., Pulay, G., Pályi, K., Németh, E., \& Mészáros, L. (2016). Supreme Audit Institutions' contribution to good governance: Study series No 1. Hungary: State Audit Office of Hungary.

Farwati, R. (2012). Pro-poor growth: does it work in Indonesia? Institute of Social Studies.

Flick, U. (2009). An introduction to qualitative research (4th ed.): SAGE Publications Ltd.

Funnell, W., Wade, M., \& Jupe, R. (2016). Stakeholder perceptions of performance audit credibility. Accounting and Business Research, 46(6), 601619.

Gustavson, M. (2015). Does good auditing generate quality of government? QoG Working Paper Series.

Harding, J. (2013). Qualitative data analysis: From start to finish. Los Angeles: SAGE.

Ijeoma, N. B., \& Nwufo, C. I. (2015). Impediments of the audit function in the public sector: A critical analysis of the constraints of Auditor-General for the Federation of Nigeria. International Journal of Economics, Commerce and Management, 3(1).

INTOSAI. (1977). ISSAI 1 The Lima Declaration. Vienna: INTOSAI. 
INTOSAI. (2001). Independence of Supreme Audit Institutions (SAIs) project: final task force report. Vienna: INTOSAI.

INTOSAI. (2010). ISSAI 2O-Principles of transparency and accountability. Vienna: INTOSAI.

INTOSAI. (2013a). ISSAI 12 - the value and Benefits of Supreme Audit Institutions - making a difference to the lives of citizens. Vienna: INTOSAI.

INTOSAI. (2013b). ISSAI 10o- Fundamental principles of public sector auditing. Vienna: INTOSAI.

Ittonen, K. (2010). A theoretical examination of the role of auditing and the relevance of audit reports. Proceedings of the University of Vaasa.

Jesus, M. A. J., \& Eirado, J. S. B. (2012). Relevance of accounting information to public sector accountability: a study of Brazilian federal public universities. Tekhne-Review of Applied Management Studies, 1O(2), 87-98.

Kaya, L. G., \& Coşkun, A. (2017). Enhancing accountability for making cities resilient and role of Supreme Audit Institutions. Mehmet Akif Ersoy Üniversitesi Sosyal Bilimler Enstitüsü Dergisi, 9(19), 445-456.

Ling, T., \& Dijk, L. V. v. (2009). Performance audit handbook: routes to effective evaluation RAND. Santa Monica: RAND Corporation.

Lungeanu, E. (2015). Considerations regarding the external public audit of reimbursable funds. Procedia Economics and Finance, 2O, 358-364.

Madison, K. J. (2014). Agency theory and stewardship theory integrated, expanded, and bounded by context: an empirical investigation of structure, behavior and performance within family firms. (Ph.D), University of Tennessee.

Mamidu, A. I., Balogun, A., \& Abilogun, T. O. (2015). Supreme Audit Institutions and public financial accountability in Nigeria: matters arising. Journal of educational research in Natural and social sciences, 1(1).

Masood, A., \& Afzal, M. (2016). Determinants of audit quality in Pakistan.
Journal of Quality and Technology Management, 12(2), 25 - 49.

Masood, A., \& Lodhi, R. N. (2015). Factors affecting the success of government audits: a case study of Pakistan. Universal Journal of Management, 3(2), 52-62.

Matendera, K. H. (2013). A survey of factors affecting public audit institutions performance- The Case of Kenya National Audit Office. Retrieved from http://erepository.uonbi.ac.ke/ bitstream/handle/11295/59867/A\% 20Survey\%20Of\%20Factors\% 20Affecting\%20Public\%20Audit\% 20Institutions\%20Performance\% 3A\%20The\%2oCase\%2oOf\% 20Kenya\%20National\%20Audit\% 20Office? sequence $=4$ \&isAllowed $=\mathrm{y}$

Meier, A., Boivin, M., \& Meier, M. (2008). Theme-analysis: procedures and application for psychotherapy research. Qualitative Research in Psychology, 5(4), 289-310.

Nagy, S. (2012). The role of Supreme Audit Institutions in fight against the consequences of financial and economic crisis: a theoretical approach. Paper presented at the Crisis Aftermath: Economic policy changes in the EU and its Member States, Szeged, University of Szeged.

Nagy, S. (2015). Supreme audit institutions and new aspects for public value creation in complex adaptive systems. In E. Hetesi \& Z. Vas (Eds.), New Ideas in a Changing World of Business Management and Marketing: University of Szeged.

Ngulube, P. (2015). Qualitative data analysis and interpretation: systematic search for meaning. Noordywk: Mosala-MASEDI Publishers \& Booksellers.

Nurhasanah. (2016). Effectiveness of internal control, internal audit, characteristics of the institution and corruption cases (an empirical study in the ministries / institution). Jurnal Tata Kelola \& Akuntabilitas Keuangan Negara, 2(1), 27-48. doi: 10.28986/ jtaken.v2i1.35

OECD. (2011). Good practices in supporting supreme audit institutions. Paris: Organisation for Economic Cooperation and Development. 
Otalor, J. I., \& Eiya, O. (2013). Combating corruption in Nigeria: the role of the public sector auditor. Research Journal of Finance and Accounting, 4(4).

Prabowo, T. J. W., Leung, P., \& Guthrie, J. (2017). Reforms in public sector accounting and budgeting in Indonesia (2003-2015): confusions in implementation. J. of Public Budgeting, Accounting \& Financial Management, 29(1), 104-137.

Pramono, A. J. (2016). Analysis of influencing factors of the audit board of republic Indonesia's roles and capabilities transformation. Jurnal Tata Kelola \& Akuntabilitas Keuangan Negara, 2 (2), 175-193. doi: 10.28986/ jtaken.v2i2.63

Raaum, R. B., \& Morgan, S. L. (2009). Performance auditing: a measurement approach. New York: The Institute of Internal Auditor Research Foundation.

Ramírez, J. A. O., \& Pérez, J. A. C. (2016). Impact of supreme audit institutions on the phenomenon of corruption: an international empirical analysis. Journal of Public Governance and Policy: Latin American Review, 2(3).

Raudla, R., Taro, K., Agu, C., \& Douglas, J. W. (2015). The impact of performance audit on public sector organizations: the case of Estonia. Public Organization Review, 16(2), 217-233.

Reichborn-Kjennerud, K., Carrington, T., Gonzales, B., \& Klarskov, K. (2015). Supreme audit institutions' role in fighting corruption: a comparative study between SAIs with different institutional and public administrative structures and cultures. Paper presented at the IRSPM workshop Birmingham, Great Britain.

Reichborn-Kjennerud, K., \& Vabo, S. I. (2017). Performance audit as a contributor to change and improvement in public administration. Evaluation, 23(1), 6-23.

Riddell, R. (2004). Sustainable urban planning: tipping the balance. Malden: Blackwell Publishing Ltd.

Rios, A. M., Bastida, F., \& Benito, B. (2016). Budget transparency and legislative budgetary oversight: an international approach. American Review of Public Administration, 46(5), 546-568.

Ritchie, J., Lewis, J., Nicholls, C. M., \& Ormston, R. (2013). Qualitative research practice: a guide for social science students and researchers. Los Angeles: SAGE.

Schultz, D. E. J., \& Brown, R. E. (2003). Performance auditing in Ohio: a customer service orientation. Journal of Government Financial Management.

Suartama, I. K., Nurdin, S., \& Susilo, F. S. B. P. (2015). Enhancing BPK RI's audit design for people's welfare: a practical approach. Jurnal Tata Kelola \& Akuntabilitas Keuangan Negara, 1(2), 173190. doi: 10.28986/jtaken.v1i2.25

The JakartaPost. (2016, March 19, 2016). Jokowi orders study into graft-tainted Hambalang project. The Jakarta Post.

Vaismoradi, M., Turunen, H., \& Bondas, T. (2013). Content analysis and thematic analysis: implications for conducting a qualitative descriptive study. Nursing and Health Sciences, 15, 398-405.

Waring, C. G., \& Morgan, S. L. (2007). Public sector performance auditing in developing countries. Washington DC: The World Bank.

Wibowo, A., Jusoh, H., Ahmad, H., \& Malek, J. A. (2018). Developmental audit design on low cost housing (Rusunawa) program in Indonesia: Identification of Rusunawa program components. Paper presented at the ICOSH-UKM 2018 the 7th International Conference on Social Sciences and Humanities, Universiti Kebangsaan Malaysia.

Wibowo, A., Jusoh, H., Ahmad, H., \& Malek, J. b. A. (2016). Developmental audit: toward a new role of public sector auditing in development. Journal of Built Environment, Technology and Engineering, 1(1), 25-35.

Wilhelm, V., \& Fiestas, I. (2005). Exploring the link between public spending and poverty eduction: lessons from the 90s. The World Bank Institute Working Paper. Retrieved from http:// siteresources.worldbank.org/WBI/ Resources/ExploringtheLink _FINAL_with_cover.pdf

World Bank. (2012). Targeting poor and vulnerable households in Indonesia. Washington, DC: The World Bank. 


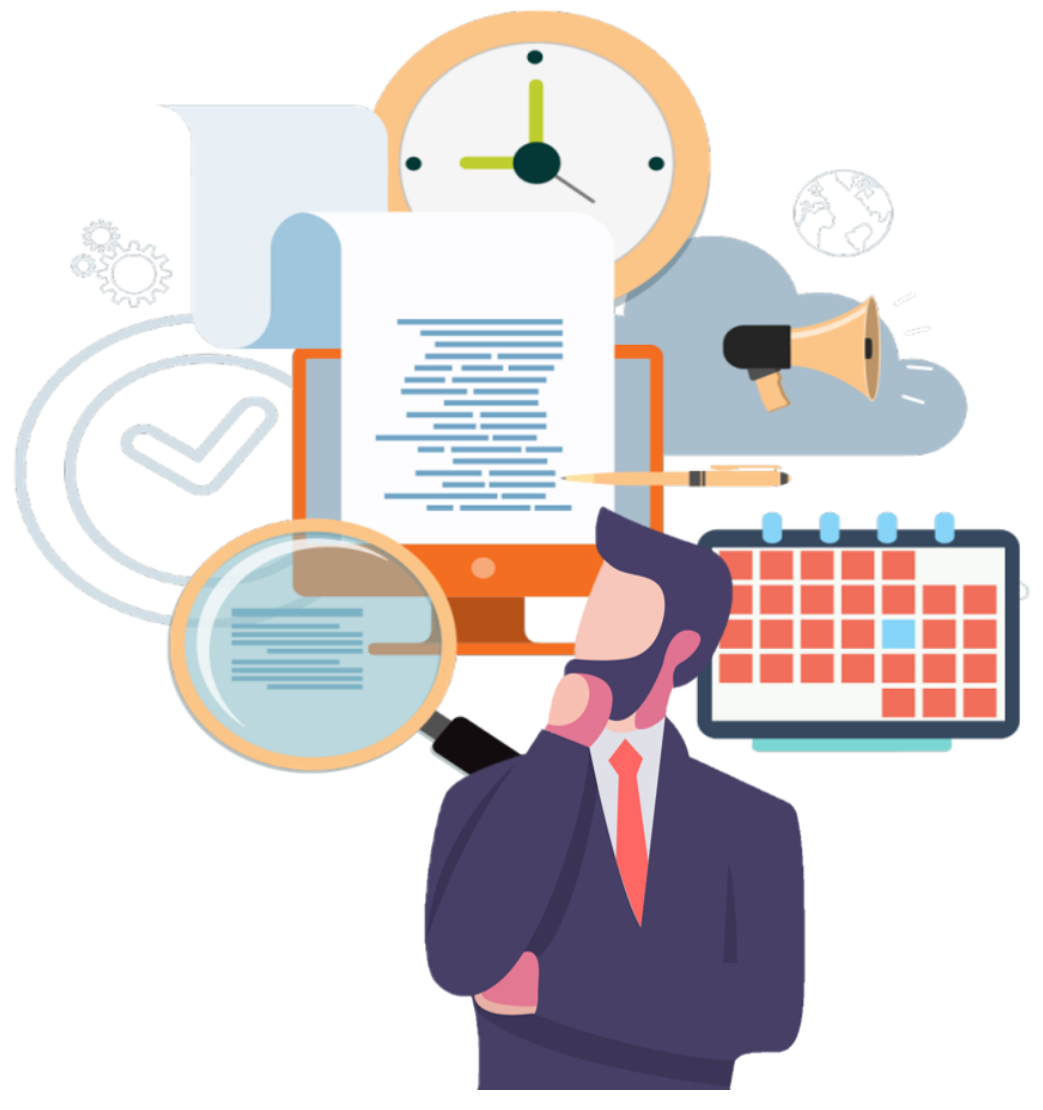

